prof. dr hab. Leszek Rudnicki

\title{
Zarządzanie finansami w gospodarstwach domowych
}

\section{Wstęp}

Głównym celem gospodarstwa domowego jest zaspokojenie potrzeb i aspiracji jego członków. Aby to osiągnąć, musi ono prowadzić odpowiednią politykę w zakresie finansów. Warunkiem zaspokojenia potrzeb i aspiracji jest posiadanie odpowiednich dochodów i umiejętne gospodarowanie nimi. Wskutek ograniczeń budżetowych konsumenci stają przed koniecznością rozpatrywania wielu spraw finansowych i podejmowania decyzji dotyczących wydatków, oszczędności, pożyczania i inwestowania.

Gospodarowanie finansami stało się w ostatnich latach skomplikowane. W wielu transakcjach gotówkę zastąpiły karty kredytowe oraz płatności elektroniczne. Pojawiło się mnóstwo usług kredytowych, co sprawiło, że sytuacja finansowa wielu gospodarstw domowych stała się mniej przejrzysta - nawet dla samych tych gospodarstw.

Aspekt finansowy jest obecny w całej działalności gospodarstwa domowego - w kupowaniu, wypożyczaniu oraz utrzymywaniu dóbr. Odgrywa on też znaczącą rolę przy podejmowaniu decyzji dotyczącej sposobu zapłaty za jakiś nabytek - czy kupić za gotówkę, czy na kredyt. $Z$ tych względów zachowania finansowe gospodarstw domowych stały się przedmiotem zainteresowania coraz to szerszego grona różnych instytucji gospodarczych, przede wszystkim banków 
i towarzystw ubezpieczeniowych. Poznanie i zrozumienie tych zachowań przez banki i towarzystwa ubezpieczeniowe jest warunkiem przyciągnięcia konsumentów o wysokiej zdolności kredytowej.

Zachowaniami finansowymi gospodarstw domowych interesują się nie tylko instytucje finansowe, ale także i władze państwowe. Dla tych ostatnich znajomość zachowań finansowych gospodarstw domowych ma znaczenie przy organizowaniu pomocy dla konsumentów, którzy znaleźli się w sytuacji problematycznego zadłużenia. Zwrócenie uwagi na zarządzanie gotówką, oszczędzanie i pożyczanie jest również ważne z punktu widzenia ochrony konsumenta. Jednym z celów państwowej polityki wobec konsumenta jest ochrona gospodarstw domowych o niskich dochodach, zwłaszcza przed mylącymi informacjami dotyczącymi możliwości kredytowych i wszelkimi błędami finansowymi, które mogą być ich następstwem.

\section{Podejmowanie decyzji finansowych}

W każdym gospodarstwie domowym podejmowane są różne decyzje finansowe. Decyzje te dotyczą: gospodarowania środkami finansowymi, finansowania zakupów, gromadzenia oszczędności oraz inwestowania i pomnażania majątku. Decyzje dotyczące tych zagadnień mogą być podejmowane indywidualnie lub zbiorowo wspólnie przez wszystkich członków gospodarstwa domowego, przy czym te ostatnie mogą być podejmowane w różnym układzie osobowym, np. mąż i żona, rodzice wraz z dziećmi, wszyscy członkowie gospodarstwa domowego'.

1 I. Smith, Meeting customer needs, Oxford 2008, s. 32. 
Ważnym czynnikiem kształtującym zachowania finansowe konsumentów jestrola męża i żony w podejmowaniu decyzji w rodzinie. W zależności od tego, jaką rolę mąż i żona odgrywają przy podejmowaniu decyzji, można wskazać pięć rodzajów zarządzania finansami przez pary małżeńskie²:

- przy dominującej roli męża finansami zarządza mąż i dostarcza żonie pieniądze na codzienne zakupy domowe;

- przy zarządzaniu wspólnym z większym udziałe m $\mathrm{m}$ ęża sprawami finansowymi zajmują się oboje małżonkowie. Mają wspólne konto bieżące i oszczędnościowe. Mąż płaci rachunki, czuwa nad spłatą kredytu hipotecznego i przeprowadza większość transakcji finansowych. Ten rodzaj zarządzania finansami występuje głównie w gospodarstwach domowych mających wyższe dochody;

- przy zarządzaniu samodzielnym mąż i żona prowadzą swoje własne sprawy finansowe i mają własne konta bieżące i oszczędnościowe. Tylko w wypadku ważnych zakupów porozumiewają się ze sobą. Ten rodzaj zarządzania finansami występuje głównie w gospodarstwach mających wysokie dochody, np. gdy dochody mają oboje małżonkowie;

- przy zarządzaniu wspólnym z większym udziałe m $\dot{z}$ o n y sprawami finansowymi zajmują się oboje małżonkowie. Transakcje finansowe przeprowadza żona. Ten rodzaj zarządzania występuje głównie w gospodarstwach mających przeciętne dochody;

- przydom in ując ej roli ż on y wszystkie sprawy finansowe prowadzi żona i daje mężowi kieszonkowe na własne wydatki. Ten

2 Por. G. Antonides, W. F. Van Raaij, Zachowanie konsumenta. Podręcznik akademicki, przekł. M. Zagrodzki, Warszawa 2003, s. 446-447. 
rodzaj zarządzania występuje głównie w gospodarstwach domowych o niskich dochodach.

Przedstawione rodzaje zarządzania finansami są w rzeczywistości bardziej złożone i w znacznym stopniu zależą od tego, kto zarabia pieniądze, kto robi zakupy i kto płaci rachunki. Sposób podejmowania decyzji w dużej mierze zależy także od zgodności charakterów obojga małżonków. Zgodny charakter sprzyja podejmowaniu przez męża i żonę wspólnych decyzji. Niezgodność charakterów prowadzi zwykle do indywidualnego podejmowania decyzji przez każdego z małżonków, często sprzecznych.

Trzeba zauważyć, że główny żywiciel rodziny ma na ogół większy wpływ na zarządzanie finansami niż inni członkowie gospodarstwa domowego. Ważną rolę odgrywa również posiadana wiedza z zakresu finansów. Ktoś, kto jest z wykształcenia księgowym, często zajmuje się także finansami gospodarstwa domowego.

\section{Gospodarowanie środkami finansowymi}

Większość swoich potrzeb konsumenci zaspokajają za pomocą produktów, w których posiadanie wchodzą na drodze ich zakupu. „Robienie zakupów ma charakter zarówno instrumentalny, jak i hedonistyczny-odpowiednio robienie zakupów codziennych i zakupów dla przyjemności. Funkcja hedonistyczna może mieć wymiar zarówno jednostkowy, jak i społeczny. Człowiek zyskuje nowe doświadczenia i spotyka innych ludzi. Zakupy mogą sprawiać przyjemność i dla wielu konsumentów stanowią formę odpoczynku. Świadczy o tym masa kupujących pojawiających się w sklepach w niedzielę ${ }^{\text {”3. }}$.

3 G. Antonides, W. F. Van Raaij, Zachowanie konsumenta..., dz. cyt., s. 438. 
Nie każdy zakup jest odczuwany przez konsumentów jako przyjemność. Jedynie zakupy dóbr wybieralnych lub okresowego zakupu, np. ubrań, biżuterii, komputerów osobistych czy samochodów, mogą być przyjemnością. Natomiast codzienne zakupy rzeczy niezbędnych uważane są za zajęcia konieczne i ważne, lecz niesprawiające przyjemności.

W wielu gospodarstwach domowych za zakupy, płacenie rachunków i inne zadania związane z zarządzaniem finansami odpowiedzialna jest jedna osoba. Rolę nabywcy w jednoosobowym gospodarstwie domowym pełni zwykle sam konsument. W gospodarstwach wieloosobowych rola nabywcy jest podzielona między kilka osób lub jest spełniana przez osobę szczególnie do tego predysponowaną. Najczęściej jest nią mąż lub żona.

Role męża i żony w inicjowaniu zakupu, zbieraniu informacji na temat produktu oraz w podejmowaniu ostatecznej decyzji zakupu, a także w odniesieniu do poszczególnych elementów zakupu są zróżnicowane. Mąż częściej podejmuje decyzje zakupu niż żona, gdy ma on wyższy od żony poziom wykształcenia i status zawodowy, gdy żona nie pracuje zawodowo, gdy w rodzinie jest dużo dzieci oraz we wczesnych fazach małżeństwa - gdy dzieci są małe. Mąż częściej podejmuje również decyzję zakupu artykułów drogich, mających często znaczenie prestiżowe. Żona natomiast podejmuje częściej niż mąż decyzje zakupu produktów związanych z wyposażeniem mieszkania oraz prowadzeniem gospodarstwa domowego. Trzeba zauważyć, że jednostka jako konsument zachowuje się inaczej, gdy występuje na rynku jako pojedyncza osoba, a inaczejjako członek rodziny. Warto zauważyć, że konsument stosunkowo rzadko występuje na rynku jedynie w swoim imieniu i tylko w odniesieniu do małej części zasobów finansowych rodziny decyduje 
o zakupach samodzielnie, na podstawie własnych preferencji. Przeważnie występuje on na rynku jako członek rodziny, wówczas decyzje zakupu produktów są wynikiem różnych postaw, wyobrażeń i preferencji członków rodziny.

Zachowania gospodarstw domowych na rynku są bardzo zróżnicowane. Mogą one być racjonalne lub irracjonalne. Gospodarstwo domowe zachowujące się racjonalnie planuje zakupy. Konfrontuje wydatki ze swymi dochodami i podejmuje wyważone decyzje odnośnie do ich wydatkowania. Racjonalnie zachowujący się konsument to taki, który idzie do sklepu z listą zakupów i kupuje zgodnie z nią. Konsument, który nie konfrontuje zawartości swojego koszyka czy wózka ze sporządzoną wcześniej listą potrzebnych produktów, kupuje znacznie więcej niż ten, który kontroluje. Warto też zauważyć, że lista zakupów pozwala omijać liczne pułapki zastawiane przez handlowców na konsumentów w celu nakłonienia ich do zakupu odpowiednie eksponowanie towaru w sklepie i ułożenie go na półkach, oświetlenie sklepu, zapachy, dobrana muzyka, konstrukcja cen $(99,99 \mathrm{zl})$ itd.

Zachowania irracjonalne to zakupy bez planu. Tak zachowujący się konsumenci, robiąc zakupy, kierują się tym, co widzą na półkach. Idą wzdłuż regałów i uświadamiają sobie, że potrzebują pomarańczy, wiśni w czekoladzie, kakao albo kawy. Ta metoda robienia zakupów sprawia, że kupują więcej, niż zamierzali, często rzeczy niepotrzebne. Konsumentów zachowujących się w ten sposób łatwiej jest skłonić, by kupili więcej niż to, co niezbędne ${ }^{4}$.

4 Por. D. W. Rook, The buying impulse, "Journal of Consumer Research" (1987) nr 1, s. 189-199. 
Wielu konsumentów często kupuje produkty, których przed wejściem do sklepu nie zamierzali kupić. Jest to kupowanie pod wpływem odruchu, często wskutek nagłego, niepohamowanego impulsu. Jest to zachowanie irracjonalne. Trzeba jednak zauważyć, że zakup pod wpływem impulsu występuje w różnym nasileniu i nie zawsze jest on zakupem niezaplanowanym, mimo że kupiony produkt nie znajduje się na liście zakupów.

Zachowania gospodarstw domowych na rynku mają wpływ na stan ich finansów. Gospodarstwo domowe kupujące produkty może zaoszczędzić bądź też wydać więcej, niż zarabia. Racjonalny konsument, analizując wydatki, może zapobiegać nadmiernemu i niepotrzebnemu odchudzaniu swego portfela. Istnieje wiele możliwości racjonalizacji wydatków i przez to obniżenia ich wysokości. I tak np. produkty spożywcze opłaca się kupować w super- czy hipermarketach, w których jest taniej niż w tradycyjnych sklepach spożywczych. Oszczędności, jakie można poczynić w skali miesiąca, kupując w dużych marketach, są spore.

W celu zaoszczędzenia pieniędzy, a także i czasu poświęcanego na zakupy, gospodarstwa domowe stosują często pewne strategie robienia zakupów. Możliwe są następujące strategie $e^{5}$ :

- kupowanie wszystkich produktów w dużych supermarketach;

- kupowanie wszystkich produktów w sklepach specjalistycznych, np. z pieczywem, warzywami i mięsem;

- kupowanie raz $\mathrm{w}$ tygodniu w supermarkecie, a pozostałych rzeczy w sklepach specjalistycznych;

5 Por. G. Antonides, W. F. Van Raaij, Zachowanie konsumenta..., dz. cyt., s. 434 . 
- kupowanie raz w tygodniu w sklepie dyskontowym, a pozostałych rzeczy w sklepach specjalistycznych;

- kupowanie raz $\mathrm{w}$ tygodniu w sklepie dyskontowym, a pozostałych rzeczy w supermarkecie.

Pierwsza i druga strategia uwzględniają tylko jeden podstawowy sklep. Następne strategie obok sklepu podstawowego uwzględniają również sklepy dodatkowe dla zakupów uzupełniających. W tych ostatnich konsumenci kupują rzeczy, których w sklepie podstawowym brak albo są złej jakości, a także artykuły łatwo psujące się, np. nabiał.

Rozsądne zakupy to także korzystanie z promocji i sezonowych wyprzedaży. W przypadku takich zakupów należy jednak zachować pewną ostrożność $\mathrm{z}$ uwagi na różne zabiegi stosowane przez sprzedawców. I tak np. atrakcyjne obniżki cen mogą wcale nie być obniżkami, bo rzekomo wyższe ceny nigdy nie obowiązywały.

Gospodarstwa domowe dokonują zakupów nie tylko w tradycyjnych sklepach, ale również na bazarach czy placach targowych, gdzie może nabyć produkt po niższej cenie niż w sklepie.

\section{Regulowanie zobowiązań}

Za zakupione produkty gospodarstwa domowe płacą w różny sposób - gotówką, kartą płatniczą. Dokonują również płatności przelewem. Dotyczy to zwłaszcza płatności regularnych, takich jak czynsz, media albo składki ubezpieczeniowe. Płatności tych konsumenci mogą dokonywać w banku osobiście. Mogą one być też przekazywane przelewem jako stałe zlecenie albo przez bezpośredni debet.

Nowoczesną formą są coraz częstsze elektroniczne transakcje bankowe dokonywane $\mathrm{w}$ domu za pośrednictwem komputera. Wiele 
płatności konsumenci realizują gotówką . Jest to tradycyjna metoda płacenia rachunków i forma płacenia bezpośredniego. Oznacza to regulację należności bezpośrednio przy ladzie lub w kasie.

Konsumenci małe sumy płacą na ogół gotówką. Gotówką konsument płaci zwykle za produkty o niskiej cenie, zaspokajające podstawowe potrzeby, będące przedmiotem zakupów codziennych.

Płacenie gotówką ma swoje plusy i minusy. Konsumenci noszący przy sobie pieniądze ponoszą ryzyko ich kradzieży. Płacąc gotówką konsumenci „racjonalizują” wydatki, ograniczając je do sumy, jaką mają przy sobie. Niektórzy konsumenci wykorzystują to dla kontrolowania wydatków, nosząc przy sobie tylko ograniczoną ilość pieniędzy, co nie pozwala im wydać więcej. Jest to wyrazem samoopanowania.

Jednym ze sposobów zapłaty jest płacenie czekiem. Ten sposób zapłaty jest dla konsumenta wygodniejszy niż płacenie gotówką, zwłaszcza w przypadku nieprzewidzianych wydatków. Czekiem nazywamy pisemne zlecenie bezwzględnego wypłacenia określonej kwoty, wydane bankowi przez posiadacza rachunku bankowego7. Nazwa czeku pochodzi od arabskiego słowa ssakk oznaczającego odroczoną płatnośćs ${ }^{8}$ Czeki mają zarówno wady, jak i zalety. Dla konsumenta niewątpliwą zaletą czeku jest łatwość realizacji operacji bezgotówkowych, a także ograniczone ryzyko w razie kradzieży czeku. Wadą - łatwość sfałszowania czeku.

6 Gotówka składa się z papierowych banknotów i metalowych monet.

7 Ustawa z dnia 28 kwietnia 1939 r. - Prawo czekowe (Dz.U. nr 37, poz. 283 z późn. zm.).

8 D. Carpanetto i in., Historia powszechna. Od upadku cesarstwa rzymskiego do ekspansji islamu. Karol Wielki, t. 7, Madrid 2007, s. 283. 
Czeki jako środek płatniczy znalazły szerokie zastosowanie głównie w krajach anglosaskich. W Polsce nie cieszyły się większą popularnością.

Wielu konsumentów dokonuje płatności kartami płatniczymi. Można je uważać za ekwiwalent gotówki. Ich zalety sprawiają, że cieszą się one coraz większą popularnością.

Karta płatnicza to karta „identyfikująca wydawcę i upoważnionego posiadacza, uprawniająca do wypłaty gotówki lub dokonania zapłaty" . Pozwala ona na podejmowanie gotówki z bankomatu lub dokonywanie bezgotówkowych płatności za towary i usługi.

Posiadacz karty płatniczej nie musi nosić ze sobą gotówki, bowiem za pomocą karty może regulować swoje zobowiązania z różnych tytułów. Można nią zapłacić praktycznie we wszystkich placówkach handlowo-usługowych: w sklepie, w aptece, na stacji benzynowej, na autostradzie czy w serwisach naprawy sprzętu AGD.

W Polsce karty płatnicze są narzędziem stosunkowo nowym. Pierwsze karty płatnicze pojawiły się u nas pod koniec lat 60. ubiegłego wieku. Rozwój kart płatniczych w naszym kraju nastąpił w latach 90. XX wieku. Znaczne ożywienie nastąpiło jednak dopiero po 1994 roku (zob. rys. 1). Obserwowany dynamiczny rozwój rynku kart płatniczych przyczynił się do tego, że karty stały się u nas najczęściej używaną formą bezgotówkowych rozliczeń pieniężnych stosowaną w płatnościach detalicznych ${ }^{10}$.

9 Ustawa z 29 sierpnia 1997 r. Prawo bankowe, Dz.U. 1997 nr 140 poz. 939, art. 4 pkt. 4.

10 Por. NBP Departament Komunikacji Społecznej, Rynek kart płatniczych w Polsce, Warszawa 2003, s. 6. 
Rysunek 1: Liczba wyemitowanych kart płatniczych w latach 1998-2011

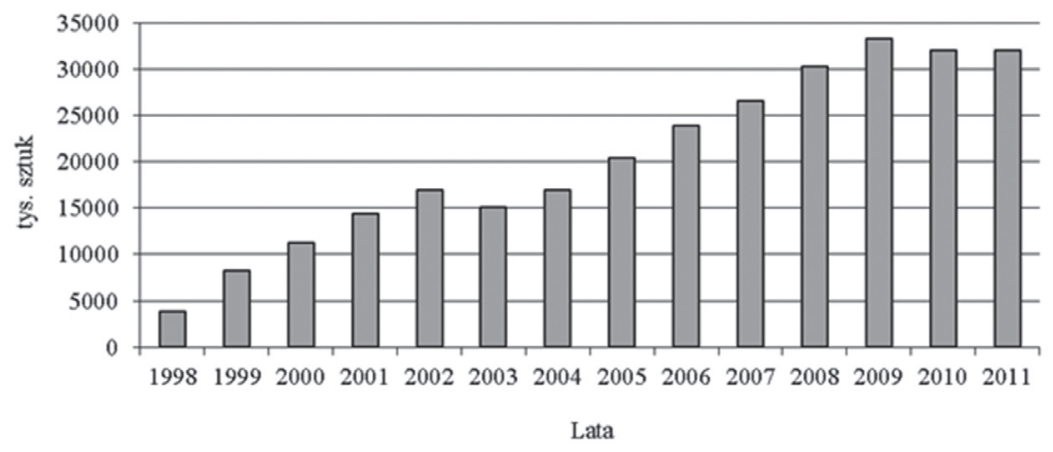

Źródło: Opracowanie własne na podstawie materiałów NBP (http://www.nbp.pl).

Karty płatnicze stały się w Polsce niemal powszechnym środkiem płatności, bez którego trudno sobie wyobrazić większość transakcji. Obecnie banki oferują konsumentom bardzo różne karty płatnicze. W zależności od przyjętego kryterium podziału można je różnie klasyfikować. Jednym z częściej stosowanych kryteriów podziału kart płatniczych jest sposób rozliczania transakcji. Według tego kryterium wyróżniamy karty: kredytowe, debetowe, obciążeniowe, przedpłacone (nazywane także elektronicznymi portmonetkami) ${ }^{11}$.

Zmiany w metodach płacenia i związane z nimi zachowania mogą w znacznym stopniu wpłynąć na wydawanie i oszczędzanie pieniędzy przez konsumenta. Wskutek stosowania czeków, kart kredytowych i debetowych oraz innych form płatności elektronicznych

11 A. Bury, Karty ptatnicze w Polsce, Warszawa 2002, s. 27-28; M. Smaga, Karty płatnicze, Zakamycze 1988, s. 22; J. Kukulski, Karty ptatnicze, Warszawa 2002, s. 21. 
płacenie staje się rodzajem administrowania rachunkiem. W wielu wypadkach płacenie gotówką nie jest konieczne. Przekraczanie stanu konta jest rzeczą powszechną i może zostać uzgodnione z góry jako forma kredytu odnawialnego. Wskutek tego konsumenci często mają mniejszy wgląd w swoją sytuację finansową, niż gdyby nadal płacili gotówką.

\section{Oszczędności}

Zarządzanie finansami w gospodarstwach domowych poza regulowaniem bieżących stałych zobowiązań obejmuje także tworzenie i utrzymywanie oszczędności. Możliwość oszczędzania pojawia się dopiero wtedy, gdy środki finansowe gospodarstwa domowego są na tyle duże, że po zaspokojeniu jego podstawowych potrzeb pozostaje nadwyżka finansowa. Umiejętność takiego gospodarowania pieniędzmi, by dochody zawsze byly większe od wydatków - to źródło bogactwa i pomyślności w życiu. Takie gospodarowanie pieniędzmi jest źródłem oszczędności.

Niezbędnym warunkiem oszczędzania jest odpowiednie dostosowanie wydatków do dochodów. Przez niedostosowanie można popaść w tarapaty finansowe - efektem jest brak zabezpieczenia na „czarną godzinę”, brak możliwości zapewnienia lepszej przyszłości czy brak poczucia bezpieczeństwa. Dla osiągnięcia sukcesu i szczęścia konieczne jest bezpieczeństwo finansowe. Zapewnić go może odpowiedni poziom oszczędności. Aby go osiągnąć, należy przede wszystkim ${ }^{12}$ :

12 Por. M. Lipiński, Finanse osobiste. Świadome zarzadzanie własnym portfelem, Gliwice 2008, s. 145. 
- określić cele, które chcemy osiągnąć;

- zmienić sposób myślenia z konsumpcyjnego na prooszczędnościowy;

- określić optymalny poziom dochodów i wydatków;

- zmienić mechanizmy i nawyki zakupu, nie kupować pod wpływem emocji;

- ograniczyć zakupy na kredyt na rzecz zakupów finansowanych z oprocentowanych oszczędności;

- zarabiać na oszczędnościach, rozsądnie je inwestując.

Przez oszczędzanie rozumie się powstrzymanie się konsumenta od bieżącej konsumpcji na rzecz jej zwiększenia w przyszłości ${ }^{13}$. Inaczej mówiąc, oszczędzanie to zatrzymywanie pewnej określonej części swoich dochodów na przyszłość.

Oszczędzanie może mieć charakter dobrowolny lub przymusowy. Oszczędzanie dobrowolne oznacza świadomą, wolną od zewnętrznych nacisków rezygnację konsumenta z wydatkowania części swych dochodów na bieżące cele konsumpcyjne.

Do oszczędzania dobrowolnego należą wszystkie te rodzaje oszczędności, w których gospodarstwo domowe swobodnie decyduje, czy oszczędzać pieniądze, czy nie. Przykładem gromadzenia oszczędności i swobodnego ich dysponowania jest rachunek oszczędnościowy w banku. Do oszczędzania dobrowolnego zalicza się również: oszczędzanie resztowe, oszczędzanie buforowe oraz oszczędzanie na pewien cel.

13 J. Harasim, Teoretyczne aspekty gromadzenia $i$ inwestowania nadwyżek finansowych przez gospodarstwa domowe, [w:] Oszczędzanie i inwestowanie indywidualne w Polsce, red. J. Harasim, Katowice 2007, s. 14. 
Oszczędzanie resztowe, określane również jako oszczędzanie niezamierzone, występuje wówczas, gdy wydatki gospodarstwa domowego (na koniec miesiąca) nie przewyższą jego bieżących dochodów.

Oszczędzanie buforowe to gromadzenie środków pieniężnych na wypadek nieprzewidzianych zdarzeń. Tworzenie i utrzymanie tego rodzaju oszczędności wymaga od gospodarstwa domowego dyscypliny, by nie wydać ich na konsumpcję.

Oszczędzanie na pewien cel to odkładanie pieniędzy na planowane transakcje, np. na zakup jakiegoś dobra trwałego użytku, na wycieczkę zagraniczną, wakacje lub remont mieszkania.

W praktyce występują wszystkie wymienione zachowania finansowe. Jak wynika z przeprowadzonego we Francji sondażu, ludzie młodzi i samotni, stanowiący 20 proc. gospodarstw domowych, są zaangażowani tylko w oszczędzanie resztowe. 33 proc. gospodarstw domowych gromadzi oszczędności buforowe. Tyle samo gospodarstw oszczędza na pewien cel, przeważnie na zakup i wyposażenie domu ${ }^{14}$.

Cele oszczędzania polskich gospodarstw domowych przedstawiono w tabeli 1. $Z$ danych tej tabeli wynika, że Polacy oszczędzają przede wszystkim na wypadek nieprzewidzianych zdarzeń losowych - ten cel wskazywało w latach 2000-2011 około 70 proc. gospodarstw domowych. Drugie w hierarchii ważności jest zabezpieczenie finansowe okresu starości. Ważnymi celami oszczędzania gospodarstw domowych były w tym okresie: leczenie, rezerwy na wydatki konsumpcyjne oraz remont domu lub mieszkania. Przedstawiona w tabeli 1 hierarchia celów oszczędzania polskich gospodarstw

14 Por. A. Babeau, Diversite des motivations et evolution des comportements d'epargne. Audition devant la Commission de l'Epargne, Paris 1981. 
domowych wskazuje wyraźnie na dominację motywów przezornościowych.

Tabela 1: Cele oszczędzania polskich gospodarstw domowych w latach 2000-2011 (w \%)

\begin{tabular}{|c|c|c|c|c|c|c|c|}
\hline $\begin{array}{c}\text { CELE } \\
\text { OSZCZĘDZANIA }\end{array}$ & 2000 & 2003 & 2005 & 2007 & 2009 & 2011 & $\begin{array}{l}\text { ŚREDNIA } \\
\text { 2000-2011 }\end{array}$ \\
\hline $\begin{array}{c}\text { REZERWA } \\
\text { NA SYTUACJE } \\
\text { LOSOWE }\end{array}$ & 75,6 & 72,1 & 70,6 & 65,8 & 61,1 & 61,5 & 67,6 \\
\hline NA STAROŚĆ & - & 43,6 & 44,9 & 39,9 & 36,1 & 36,5 & 40,0 \\
\hline LECZENIE & 44,7 & 39,6 & 42,1 & 34,5 & 29,2 & 25,0 & 35,1 \\
\hline $\begin{array}{c}\text { REZERWA } \\
\text { NA WYDATKI } \\
\text { KONSUMPCYJNE }\end{array}$ & 40,2 & 34,8 & 31,0 & 35,1 & 30,5 & 33,2 & 34,0 \\
\hline $\begin{array}{l}\text { REMONT DOMU, } \\
\text { MIESZKANIA }\end{array}$ & 37,6 & 39,1 & 35,8 & 32,8 & 28,4 & 25,0 & 32,7 \\
\hline $\begin{array}{c}\text { NA PRZYSZŁOŚĆ } \\
\text { DZIECI }\end{array}$ & 35,0 & 31,2 & 30,9 & 28,7 & 25,0 & 23,2 & 28,7 \\
\hline WYPOCZYNEK & 30,6 & 29,3 & 31,3 & 29,5 & 26,4 & 23,5 & 28,3 \\
\hline $\begin{array}{c}\text { ZAKUP DÓBR } \\
\text { TRWAŁEGO UŻYTKU }\end{array}$ & 34,5 & 27,9 & 29,6 & 29,5 & 25,6 & 22,7 & 28,1 \\
\hline NA INNE CELE & 20,4 & 18,4 & 19,3 & 17,8 & 17,0 & 14,0 & 17,7 \\
\hline NA STAEE OPŁATY & 20,2 & 20,8 & 18,5 & 15,5 & 14,1 & 12,0 & 16,5 \\
\hline BEZ CELU & 11,3 & 9,9 & 12,2 & 8,7 & 11,4 & 10,1 & 10,5 \\
\hline $\begin{array}{l}\text { ZAKUP DOMU, } \\
\text { MIESZKANIA }\end{array}$ & 11,8 & 12,1 & 10,5 & 8,7 & 8,7 & 6,4 & 9,5 \\
\hline
\end{tabular}

Źródło: P. Anioła, Z. Gołaś, Zastosowanie wielowymiarowych metod statystycznych $w$ typologii strategii oszczędnościowych gospodarstw domowych w Polsce, Warszawa 2012, s. 41 (Materiały i Studia, 282).

Oszczędzanie przymusowe to oszczędzanie, w którym konsument przymuszony prawem rezygnuje z wydatkowania części dochodów na konsumpcję. Oszczędzanie przymusowe obejmuje np. przekazywanie składek emerytalnych i na ubezpieczenie na życie - tych ostatnich często na podstawie zbiorowych umów pracowniczych. 
Do oszczędzania przymusowego można zaliczyć również rezygnację gospodarstwa domowego z przeznaczenia części swoich dochodów na konsumpcję, wynikającą z przymusu ekonomicznegospowodowaną brakiem towarów na rynku.

Oszczędzanie dobrowolne uwarunkowane jest oczekiwaniami dotyczącymi dochodów i perspektywami gospodarczymi. Gospodarstwa domowe, których dochody w poprzednim roku wzrosły i które oczekują ich wzrostu w następnym roku, oszczędzają niewiele. Natomiast gospodarstwa, których dochody utrzymują się na stałym poziomie albo zmniejszyły w poprzednim roku i które nie oczekują ich wzrostu w okresie następnym, oszczędzają dużo. Inaczej mówiąc, gdy gospodarstwa domowe mają pozytywne oczekiwania dotyczące dochodów, oszczędzają mało. Natomiast jeśli mają negatywne oczekiwania - oszczędzają dużo.

Oczekiwania dotyczące dochodów wpływają zarówno na sposób oszczędzania, jak i na wysokość oszczędzanych sum. Pozytywne oczekiwania gospodarstw domowych dotyczące dochodów powodują, że mniej oszczędzają, a więcej pożyczają. W przypadku negatywnych oczekiwań gospodarstwa więcej oszczędzaja, a mniej pożyczają.

Negatywne oczekiwania gospodarstw domowych odnośnie do dochodów przyczyniają się zwykle do tego, że dążą one do zgromadzenia oszczędności buforowych na wypadek nieprzewidzialnych zdarzeń oraz zapewnienia sobie stabilności finansowej w przyszłości. Zwykle też boją się robienia dużych zakupów, zwłaszcza na kredyt.

Na oszczędzanie wpływają nie tylko oczekiwania odnośnie do dochodów, ale także oprocentowanie wkładów i inflacja. Te ostatnie dają konsumentom odpowiedź na pytanie o sens oszczędzania. Odpowiedź 
pozytywna skłania do oszczędzania. Natomiast gdy stopa procentowa jest niska, a inflacja duża - oszczędzanie nie jest rzeczą rozsądną.

Inflacja jest zjawiskiem w zasadzie stale towarzyszącym gospodarce. W Polsce w latach 2001-2012 kształtowała się ona w granicach od 0,7-4,3 proc. W roku 2012 wynosiła 3,7 proc. O tyle spadła wartość naszych pieniędzy w ciągu roku.

Gospodarstwo domowe pragnące zabezpieczyć swoje pieniądze przed utratą ich wartości poszukuje zatem narzędzi, które pozwolą mu jeśli nie całkowicie wyeliminować, to przynajmniej w znacznym stopniu ograniczyć to zjawisko. Jednym z takich instrumentów są lokaty, pod warunkiem że są one odpowiednio oprocentowane. I tak np. uważa się, że przy inflacji rzędu 3,5 proc. ochronę oszczędności gwarantuje oprocentowanie lokaty powyżej 4,33 proc. w skali roku ${ }^{15}$. Takie oprocentowanie oszczędności nie zapewnia jednak osiągnięcia zysku z kapitału, nie skłania więc gospodarstw domowych do oszczędności.

Trzeba jednak zauważyć, że nie wszystkie rachunki bankowe zabezpieczają pieniądze konsumenta przed utratą ich wartości takim rachunkiem jest na przykład rachunek oszczędnościowo-rozliczeniowy, gdzie oprocentowanie jest symboliczne lub zgoła nie występuje. Nie powinien więc służyć do oszczędzania. Konsument wykorzystujący ten rachunek do gromadzenia oszczędności oddaje swoje pieniądze na pastwę inflacji.

Wypada też zauważyć, że skłonność do oszczędzania w polskich gospodarstwach domowych jest niska. Wskazują na to zarówno dane NBP, jak i wyniki badań prowadzonych w Polsce przez

15 K. P. Łabenda, Budżet domowy pod kontrola, Gliwice 2011, s. 91. 
różne instytucje badawcze. Informują one, że w latach 1995-2012 brak jakichkolwiek oszczędności deklarowało aż 70-80 proc. Polaków. Z badań tych wynika również to, że wśród nielicznej grupy oszczędzających dominują wyraźnie osoby, które miały najniższe oszczędności, tj. na poziomie dochodów z ostatnich trzech miesięcy. Odsetek osób z oszczędnościami na tym poziomie wśród ogółu oszczędzających wahał się w latach 1995-2012 w przedziale 63-73 proc. ${ }^{16}$.

\section{Inwestycje}

Oszczędzanie polega na odkładaniu pieniędzy na jakieś cele. Jeżeli gospodarstwo domowe zaoszczędziło dostatecznie dużo pieniędzy, by pokryć niezbędne późniejsze wydatki, rozważa możliwość lokowania swoich walorów w inwestycje. Inwestowanie to dysponowanie oszczędnościami na rzecz przyszłych korzyści. Jest to każde wykorzystanie kapitału w celu jego powiększenia.

Inwestując, gospodarstwo domowe podejmuje decyzje o lokowaniu środków pieniężnych w różnego rodzaju przedsięwzięcia, wyrażające się w:

- pozyskiwaniu rzeczowych składników majątkowych drogą zakupu (nieruchomości, spółek itp.);

- wytwarzaniu majątku rzeczowego we własnym zakresie (budowa domu);

16 Por. P. Anioła, Z. Gołaś, Zastosowanie wielowymiarowych metod statystycznych $w$ typologii strategii oszczędnościowych gospodarstw domowych $w$ Polsce, Warszawa 2012, s. 27-29 (Materiały i Studia, 282). 
- zakupie lub tworzeniu nowych wartości majątkowych o charakterze nieużytkowym (dzieła sztuki, metale szlachetne);

- nabywaniu papierów wartościowych (np. akcje, obligacje, bony skarbowe $)^{17}$.

Wyróżnia się więc inwestycje rzeczowe i finansowe. W przypadku inwestycji rzeczowych przedmiot inwestycji ma charakter materialny, a gospodarstwo domowe jako inwestor oczekuje, iż wartość przedmiotu inwestycji wzrośnie w czasie. Natomiast w przypadku inwestycji finansowych przedmiot inwestycji ma charakter niematerialny. Inwestycje rzeczowe to przepływy dóbr w wyniku zamiany środków finansowych na dobra materialne w celu osiągnięcia dodatkowych dochodów w następnych okresach. Inwestycje finansowe to transfer środków pieniężnych (przepływ kapitału).

Inwestowanie jest formą zarządzania majątkiem, polegającą na tym, że człowiek świadomie podejmuje ryzyko i stara się ograniczyć je do minimum. Inwestując, gospodarstwo domowe podejmuje ryzyko, by osiągnąć większą opłacalność niż w przypadku oszczędności. Ryzyko to polega na utracie części lub całości zainwestowanych środków. Ryzyko, jakie ponosi gospodarstwo domowe, inwestując, jest mniejsze lub większe. Jest ono zależne od rodzaju przedsięwzięcia inwestycyjnego. Im większy zysk ma przynieść inwestycja, tym większe prawdopodobieństwo straty. Najbardziej ryzykowne są m.in. akcje, fundusze inwestycyjne, transakcje terminowe oraz certyfikaty depozytowe. Mniej ryzykowne są obligacje, depozyty, nieruchomości i metale szlachetne. Dzięki dokonywaniu wielu rozmaitych inwestycji ryzyko strat zostaje ograniczone do minimum.

17 M. Lipiński, Finanse osobiste..., dz. cyt., s. 178. 
Konsumenci równoważą zyski i ryzyko. Podejmują oni ryzyko tylko wówczas, gdy oczekiwane zyski są wystarczająco duże.

Tabela 2: Wartość aktywów finansowych gospodarstw domowych w Polsce w latach 2001-2010 według stanu na koniec roku w mld zł

\begin{tabular}{|c|c|c|c|c|c|c|c|c|c|c|}
\hline WYSZCZEGÓLNIENIE & 2001 & 2002 & 2003 & 2004 & 2005 & 2006 & 2007 & 2008 & 2009 & 2010 \\
\hline OGÓŁEM & 335,2 & 365,9 & 400,4 & 434,7 & 509,2 & 624,0 & 738,9 & 738,1 & 854,4 & 966,1 \\
\hline DEPOZYTY BANKOWE & 219,4 & 213,0 & 209,8 & 207,4 & 218,4 & 232,1 & 267,5 & 336,6 & 387,9 & 425,9 \\
\hline $\begin{array}{c}\text { ŚRODKI } \\
\text { ZGROMADZONE W OFE }\end{array}$ & 19,5 & 31,5 & 44,8 & 62,6 & 86,1 & 114,2 & 139,7 & 138,0 & 178,6 & 221,3 \\
\hline $\begin{array}{c}\text { FUNDUSZE } \\
\text { INWESTYCYJNE }\end{array}$ & 10,1 & 20,5 & 30,4 & 34,4 & 58,0 & 92,4 & 109,4 & 50,9 & 62,4 & 75,5 \\
\hline $\begin{array}{l}\text { UBEZPIECZENIOWE } \\
\text { FUNDUSZE KAPITAŁOWE } \\
\text { I SKŁADKI }\end{array}$ & 20,8 & 25,6 & 30,0 & 35,2 & 41,8 & 51,8 & 62,8 & 67,9 & 68,4 & 74,1 \\
\hline $\begin{array}{c}\text { AKCJE NOTOWANE } \\
\text { NA GPW }\end{array}$ & 9,7 & 8,0 & 11,2 & 18,7 & 26,0 & 44,9 & 61,3 & 28,0 & 41,9 & 51,1 \\
\hline $\begin{array}{c}\text { SKARBOWE } \\
\text { PAPIERY WARTOŚCIOWE }\end{array}$ & 16,1 & 20,5 & 19,2 & 20,4 & 16,8 & 12,5 & 10,3 & 13,3 & 12,8 & 10,1 \\
\hline $\begin{array}{c}\text { NIESKARBOWE } \\
\text { PAPIERY WARTOŚCIOWE }\end{array}$ & - & - & - & - & - & - & 3,7 & 3,0 & 2,6 & 1,9 \\
\hline DEPOZYTY W SKOK & 1,7 & 2,2 & 3,2 & 3,9 & 5,1 & 5,6 & 6,7 & 8,9 & 11,1 & 13,0 \\
\hline $\begin{array}{l}\text { GOTÓWKA W OBIEGU } \\
\text { (BEZ KAS BANKÓW) }\end{array}$ & 38,2 & 42,1 & 49,2 & 50,9 & 57,0 & 67,4 & 76,8 & 90,8 & 89,7 & 92,7 \\
\hline
\end{tabular}

Źródło: P. Anioła, Z. Gołaś, Zastosowanie wielowymiarowych metod statystycznych w typologii strategii oszczędnościowych gospodarstw domowych w Polsce, „Materiały i Studia" z. 282, Warszawa 2012, s. 34.

Wartość i strukturę aktywów finansowych gospodarstw domowych $\mathrm{w}$ Polsce przedstawia tabela $2 . \mathrm{Z}$ danych przedstawionych w tej tabeli wynika, że oszczędności ogółem polskich gospodarstw domowych wzrosły w latach 2001-2010 blisko trzykrotnie oraz że gospodarstwa domowe gromadzą środki finansowe przede wszystkim na lokatach bankowych lub w formie gotówki. Oszczędności te są w głównej mierze rezerwą na nieprzewidziane zdarzenia losowe oraz zabezpieczenie starości. 
W strategii gospodarstw domowych odnoszącej się do oszczędności dominuje opcja lokowania środków pieniężnych w bezpieczne produkty finansowe, tj. produkty bankowe - w postaci konta osobistego, lokaty terminowej oraz konta oszczędnościowego. Słabym zainteresowaniem cieszą się natomiast inwestycje w nieruchomości, fundusze inwestycyjne, lokaty inwestycyjne przy relatywnie częstym trzymaniu gotówki $\mathrm{w}$ domu ${ }^{18}$.

18 Por. Postawy Polaków wobec oszczędzania. Raport Fundacji Kronenberga przy Citi Handlowy, TNS Pentor, październik 2011, http://www.citibank.pl/ poland/kronenberg/polish/files/fk_oszcz_2011.pdf. 